Egypt. Acad. J. biolog. Sci., 1 (1): 21- 29 (2009)

Email: egyptianacademic@yahoo.com

Received: 15/11/2009
E. Medical Entom. \& Parasitology

ISSN: 2090 - 0783

www.eajbs.eg.net

\title{
Effect of extrinsic incubation temperature on transstadial and transovarial transmission of Borrelia sp. in Ornithodoros (O.) savignyi and infectivity to vertebrate host.
}

\author{
Nawal M. Shanbaky ${ }^{1}$; Nadia Helmy ${ }^{1}$; Adel Abd Elmohsen ${ }^{2}$ and \\ Amira E. Abd-Elhamid ${ }^{1}$ \\ 1- Department of Entomology, Faculty of Science, Ain-Shams University \\ 2- Research and Training Center on Vectors of Diseases, Ain-Shams University
}

\begin{abstract}
Effects of three extrinsic incubation (EI) temperatures on vector competence of Ornithodoros savignyi to Borrelia sp. isolated from a natural population of the tick in Egypt were investigated. The EI temperature influenced the efficiency of Borrelia $s p$. transmission by the female O. savignyi to hamsters. An EI temperature for $27^{\circ} \mathrm{C}$ was optimum for successful transmission of Borrelia $s p$. where the highest infection rates (IRs) in hamsters occurred. Generally, the IRs in hamsters decreased by lowering the EI temperature to $17^{\circ} \mathrm{C}$ or rising it to $37^{\circ} \mathrm{C}$ in each of the corresponding experimental cases (number and postinfection period of the tick feeding per hamster) tested.

Ornithodoros savignyi kept at $27^{\circ} \mathrm{C}$ and $37^{\circ} \mathrm{C}$ maintained borrelial infection transstadially from nymph 1 to 7 and adults. The transstadially infected stages transmitted the spirochetes to hamsters with higher IRs at $27^{\circ} \mathrm{C}$ than $37^{\circ} \mathrm{C}$. Transovarial transmission of Borrelia sp. occurred during the first and second (at higher rates) gonadotrophic cycle in the infected female ticks kept at $27^{\circ} \mathrm{C}$ and $37^{\circ} \mathrm{C}$. However, no molting or oviposition occurred at $17^{\circ} \mathrm{C}$.
\end{abstract}

Keywords: temperature, Borrelia, Ornithodoros, vertebrate

\section{INTRODUCTION}

Extrinsic temperature affects tick-pathogen relationships and transmission to the vertebrate host in various ways. Numerous studies have reported effects of temperature on biological and physiological processes in the vector tick (Cunliffe, 1922; Tatchell, 1964; Hafez et al., 1972; Khalil, 1974 and Ouhelli et al., 1987) and pathogen (Injeyan et al., 1971; Young and Leitch, 1981; Lowengrub et al., 1989 and Naumov et al., 1998) and on the susceptibility of the tick (Dalgleish and Stewart, 1982; Shih et al., 1995 and Helmy et al., 2000 a, b and 2006) and vertebrate (Ochanda et al., 1988; Shih, 1995; Schwan et al., 1995; Young et al., 2000 and Cugini et al., 2003) to infection.
High temperature affects the competence of the vector ticks by affecting the persistence of the pathogen in the vector sp. of Lyme disease and relapsing fever. Shih et al. (1995) demonstrated that the persistence of spirochetal infection of Lyme disease $B$. burgdorferi in nymphal deer tick Ixodes dammini is reduced by incubation at temperature higher than $27^{\circ} \mathrm{C}$ for longer than two weeks and spirochetes became undetectable at four weeks thereafter. Increase of temperature more than $27^{\circ} \mathrm{C}$ has been found to stimulate or inhibit synthesis of certain proteins in the spirochete $B$. burgdorferi (Cluss and Boothby, 1990; Schwan et al., 1995; Obonyo et al., 1999 and Ramamoorthy and Scholl, 2001). In addition, Lyme disease spirochete, $B$. 
burgdorferi, did not grow when cultured at temperature in excess of $37^{\circ} \mathrm{C}$ (Barbour, 1984). In contrast to findings of Shih et al,. 1995, the increase of the extrinsic incubation (EI) temperature of rearing the female O. Savignyi infected with Borrelia sp. (mostly of relapsing fever) from $17^{\circ} \mathrm{C}$ to $27^{\circ} \mathrm{C}$ and $37^{\circ} \mathrm{C}$ increased the mean number (no.), infection rate (IR) and prolonged persistence of the spirochetes in different organs of the vector tick throughout 90 days after the infective blood meal (Helmy et al., 2009).

The sand tampan, O. (O.) savignyi, collected from different localities in Egypt has been found to be naturally infected with Borrelia $s p$. (Shanbaky and Helmy, 2000 and Helmy, 2000b) and is capable of experimentally acquiring and maintaining the spirochetal infection by transstadial and transovarial transmission in the tick population and transmitting it to the vertebrate host (Shanbaky and Helmy, 2000). These three biological processes are important criteria which must be considered in evaluating the efficiency of the tick as a reservoir for Borrelia and its competence as a vector of a disease (Hoogstraal, 1985).

The present work investigates the effect of three extrinsic incubation temperatures $\left(17^{\circ} \mathrm{C}, 27^{\circ} \mathrm{C}\right.$ and $\left.37^{\circ} \mathrm{C}\right)$ on the ability of female $O$. savignyi to maintain the infection with Borrelia $s p$. within developing life stages and generations by transstadial transfer and transovarial transmission, respectively. Also, the ability of the tick to transmit infection to vertebrate host at each tested temperature at different intervals following the infective blood meal.

\section{MATERIALS AND METHODS}

\section{Tick colonies:}

Ornithodoros (O.) savignyi (Audouin), Argasidae, was collected from sand where cattle rest at
Dahshore, Giza governorate, Egypt. Field collected uninfected adults were used to start uninfected colonies and were maintained at $27 \pm 1^{\circ} \mathrm{C}, 75 \% \mathrm{RH}$ and $16 \mathrm{hrs}$ light day. Ticks were fed on hamster, Mesocricetus auratus, as described by Helmy (2000). Infected colonies started by feeding clean ticks on laboratory infected hamsters which had been fed upon by naturally infected O. savignyi. Infected colonies were kept at three different temperatures of $17^{\circ} \mathrm{C}, 27^{\circ} \mathrm{C}$ and $37^{\circ} \mathrm{C}$.

\section{Detection of spirochetes:}

Blood smears from tick and hamster (Helmy, 2000) were stained with Fontana stain (Conn et al., 1960) or with direct (DI) (Piesman et al., 1986) and indirect immunofluorescence (IDF) technique (Lane and Manweiler, 1988), respectively. For IDF, antigen slides were prepared from spirochetes obtained from the tick and cultured in modified kelly's medium (Barbour et al., 1983).

Transstadial transfer of Borrelia sp. and transmission to uninfected hamsters:

About 300 uninfected nymph $\left(\mathrm{N}_{1}\right)$ O. savignyi were fed on hamsters infected with Borrelia sp. The engorged $\mathrm{N}_{1}$ were collected and a sample of ten ticks were examined individually $1 \mathrm{hr}$ after infective blood meal. Each $\mathrm{N}_{1}$ was separately crushed in saline, stained with Fontana stain and/or DF technique and examined microscopically to ensure that spirochetes had been obtained with the infective blood meal. After the remaining $\mathrm{N}_{1}$ had molted to $\mathrm{N}_{2}, 10-20$ infected $\mathrm{N}_{2}$ were fed on each of five uninfected hamsters. The hamster blood was examined for spirochetes 47 days later. This step was repeated for each subsequent nymphal instar and adult stages. Samples of ten ticks of each subsequent instar and adult stage were tested for spirochetes. A 
drop of hemolymph (HL) was collected from broken tarsus of each tick after feeding and smeared and stained with Fontana stain and /or DF technique and examined microscopically for spirochetes transstadial transfer (TST). The aforementioned steps were repeated for ticks kept at each of the three tested temperatures.

Transovarial transmission of Borrelia $s p$. in the tick:

Laboratory reared virgin uninfected females of $O$. savignyi were fed on hamsters infected with Borrelia $s p$. Each of ten infected parent females $\left(\mathrm{P}_{1}\right)$ was placed individually in polyethylene tube with an uninfected recently fed male and observed for oviposition (first gonadotrophic cycle). When eggs hatched, $10 \mathrm{~F} 1$ larvae from each female were examined individually for spirochetes. After 30 days following first blood meal, females were offered a second but a clean blood meal, and observed for oviposition (second gonadotrophic cycle). Transovarial transmission (Tov) and filial infection rates (IRs) were calculated for females and their larval progeny (Hoogstraal, 1985) during first and second gonadotrophic cycle. These steps were repeated for tick kept at each of the three tested temperatures.

Transmission of Borrelia sp. infection from tick to hamster:

After 30, 60 and 90 days post feeding infective blood meal, different numbers $(1,3,6$ and 10 ticks) of adult female $O$. savignyi infected with Borrelia sp. isolated from the tick natural populations were fed on each of five clean uninfected hamsters. Four to seven days post feeding the tick, blood samples from each hamster was examined for spirochetes as described before. Those steps were repeated for each of the tested three temperatures.

\section{Statistical analysis:}

The percentages of the different life stages of the tick and that of Borrelia sp. infected blood samples collected from the vertebrate host were determined and compared using Chisquare test with the aid of statistical Package of Social Science (SPSS) version 8.0 for Windows.

\section{RESULTS AND DISCUSSION}

Effect of EI temperature on transstadial transfer of Borrelia sp. in $O$. savignyi and subsequent transmission to hamster:

At $17^{\circ} \mathrm{C} \quad \mathrm{N}_{1}$ failed to molt, however at $27^{\circ} \mathrm{C}$ and $37^{\circ} \mathrm{C}$ the infected $\mathrm{N}_{1}$ molted and transmitted spirochetes to $60 \%$ and $70 \%$ of the subsequent nymphal life stage $\left(\mathrm{N}_{2}\right)$ respectively (Table 1).

Table (1): The percentage of transstadial transfer of Borrelia sp.* infection in nymphal and adult $O$. savignyi kept at $27^{\circ} \mathrm{C}$ and $37^{\circ} \mathrm{C}$ and spirochete transmission form these stages to uninfected hamsters.

\begin{tabular}{|c|c|c|c|c|}
\hline \multirow{2}{*}{$\begin{array}{c}\text { Tick life } \\
\text { stage }\end{array}$} & \multicolumn{2}{|c|}{$\begin{array}{c}\% \text { infection in } \\
\text { tick HL }\end{array}$} & \multicolumn{2}{c|}{$\begin{array}{c}\text { infection in } \\
\text { hamster }\end{array}$} \\
\cline { 2 - 5 } & $27^{\circ} \mathrm{C}$ & $37^{\circ} \mathrm{C}$ & $27^{\circ} \mathrm{C}$ & $37^{\circ} \mathrm{C}$ \\
\hline $\mathrm{N}_{1 * *}$ & 100 & 100 & - & - \\
$\mathrm{N}_{2}$ & 60 & 70 & 50 & 30 \\
$\mathrm{~N}_{3}$ & 50 & 60 & 70 & 40 \\
$\mathrm{~N}_{4}$ & 60 & 70 & 80 & 50 \\
$\mathrm{~N}_{5}$ & 40 & 50 & 60 & 40 \\
$\mathrm{~N}_{6}$ & 50 & 60 & 80 & 50 \\
$\mathrm{~N}_{7}$ & 50 & 60 & 100 & 60 \\
Male & 40 & 50 & 90 & 50 \\
Female & 60 & 80 & 100 & 70 \\
\hline
\end{tabular}

*Borrelia sp. was isolated from natural population of the tick.

$* * \mathrm{~N}_{1}$ was fed on infected hamster while other stages were fed on uninfected hamster.

The IRs in HL of the following nymphal instars and adults fluctuated between $40 \%$ to $60 \%$ at $27^{\circ} \mathrm{C}$ and $50 \%$ to $80 \%$ at $37^{\circ} \mathrm{C}$ with no significant differences among them at each temperature $(\mathrm{P}>0.05)$ or between each life stage at $27^{\circ} \mathrm{C}$ and $37^{\circ} \mathrm{C}$. Spirochetes were transmitted to hamsters which were fed upon by the transstadially infected life stages $\left(\mathrm{N}_{2}-\right.$ $\mathrm{N}_{7}$ and adults). The IRs in the hamsters (Table 1) ranged from $50 \%$ to $100 \%$ and $50 \%$ to $70 \%$ at $27^{\circ} \mathrm{C}$ and $37^{\circ} \mathrm{C}$, respectively with no significant 
difference among the hamsters $(\mathrm{P}>$ 0.05 ) at each temperature. However, there was a significant decrease $(\mathrm{P}<$ 0.05) of IRs with Borrelia sp. in hamsters fed upon by each of the different transstadially infected life stages kept at $37^{\circ} \mathrm{C}$ less than at $27^{\circ} \mathrm{C}$.

These results showed that with the exception of $17^{\circ} \mathrm{C}$ (which prevented molting), the two other tested temperatures $\left(27^{\circ} \mathrm{C}\right.$ and $\left.37^{\circ} \mathrm{C}\right)$ seemed to have no significant effect on TST of Borrelia sp. in O. savignyi. However, results of Borrelia $s p$. transmission to hamster were in accordance of those by Shih et al. (1995) on $b$. burgdorferi where they found that incubation of I. dammini nymphs at temperature higher than $27^{\circ} \mathrm{C}$ for two weeks or longer were not permissive for the transmission of the spirochetes to mice.

Effect of EI temperature on transovarial transmission of Borrelia sp. in $O$. savignyi:

Female $O$. savignyi failed to oviposit at $17^{\circ} \mathrm{C}$, however $60 \%$ and $70 \%$ of infected females kept at $27^{\circ} \mathrm{C}$ and $37^{\circ} \mathrm{C}$ transmitted Borrelia sp. transovarially to their eggs and about $15 \%$ and $23 \%$ of the emerged larvae were infected with Borrelia during the first gonadotrophic cycle (Fig. 1).

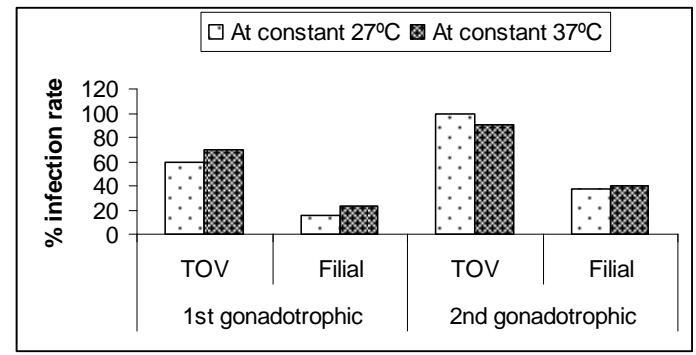

Fig. 1: Transovarial and filial infection rates of Borrelia sp. in O. savignyi during the $1^{\text {st }} \&$ gonadotrophic cycle of the parent female kept at 27 and $37^{\circ} \mathrm{C}$

A second but a clean blood meal induced higher $(\mathrm{P}<0.05)$ transovarial (100\% and 90\%) and filial $(37.5 \%$ and $40 \%)$ IRs in the same females during the second gonadotrophic cycle than that in the first gonadotrophic cycle at the two tested temperatures. There was no significant difference $(\mathrm{P}>0.05)$ between each of the percent of transovarial transmission or filial IRs of $\mathrm{F}_{1}$ larvae of $O$. savignyi when parent females were kept at $27^{\circ} \mathrm{C}$ and $37^{\circ} \mathrm{C}$ during each of the first and second gonadotrophic cycle.

Similar data were obtained by Gaber et al. (1984) and who found that infected female $O$. erraticus transmitted spirochetes, B. crocidurae transovarially to their eggs and $F_{1}$ larvae in higher percentages during the second gonadotrophic cycle than the first cycle. These findings suggested that spirochetes number progressively increases during the successive egg developmental cycles of the tick.

The dispersal of borrelial infection in various organs of $O$. savignyi (Helmy et al., 2009) and ability of the tick to transmit the spirochete transovarially and transstadially (at $27^{\circ} \mathrm{C}$ and $37^{\circ} \mathrm{C}$ and to transmit the spirochete while feeding on uninfected hamsters at the temperatures tested in the present work prove the capacity of this tick species to serve as vector and reservoir (Hoogstraal, 1985) of Borrelia sp. in Egypt. Furthermore, this suggestion is supported by the fact that the three tested temperatures are most prevailing temperatures during the year (Helmy 2000b) in Giza governorate, Egypt where the tick was collected. In accordance with the present findings the field data of Helmy (2000b) in the same locality where high prevalence of Borrelia sp. infection was found in field collected nymphs and adults of $O$. savignyi during summer months while low infection rates were found in winter months during which the highest and lowest temperatures were recorded, respectively. 
Effect of EI temperature on tick transmission of Borrelia sp. to hamsters: Adult female O. savignyi infected with Borrelia sp. transmitted the infection to hamsters fed upon at the three EI temperatures tested in the present study (Table 2).

Table (2): Effect of number and post infection time of female $O$. savignyi kept at three different temperatures on transmission of Borrelia sp. to uninfected hamsters.

\begin{tabular}{|c|c|c|c|c|c|}
\hline \multirow{2}{*}{$\begin{array}{c}\text { Infected ticks } \\
\text { No./hamster }\end{array}$} & & \multicolumn{4}{|c|}{$\begin{array}{c}\text { of infected hamsters } \\
\text { by feeding of ticks }\end{array}$} \\
\cline { 4 - 6 } $\begin{array}{c}\text { Days after } \\
\text { infective meal at } \\
\text { different temp. }\end{array}$ & Temp. & 1 & 3 & 6 & 10 \\
\hline & & & & & \\
\hline 30 & $17^{\circ} \mathrm{C}$ & 0 & 0 & 20 & 60 \\
& $27^{\circ} \mathrm{C}$ & 60 & 80 & 100 & 100 \\
& $37^{\circ} \mathrm{C}$ & 20 & 40 & 60 & 100 \\
\hline & $17^{\circ} \mathrm{C}$ & 0 & 0 & 0 & 20 \\
& $27^{\circ} \mathrm{C}$ & 40 & 60 & 80 & 100 \\
& $37^{\circ} \mathrm{C}$ & 0 & 20 & 40 & 60 \\
\hline & $17^{\circ} \mathrm{C}$ & 0 & 0 & 0 & 0 \\
& $27^{\circ} \mathrm{C}$ & 0 & 20 & 40 & 60 \\
& $37^{\circ} \mathrm{C}$ & 0 & 20 & 20 & 40 \\
\hline
\end{tabular}

At each temperature, Borrelia IRs in hamsters gradually increased $(\mathrm{P}$ $<0.05)$ by increasing the number of infected ticks feeding on each hamster from six to ten and from one to ten at $17^{\circ} \mathrm{C}$ and $27^{\circ} \mathrm{C}$ or $37^{\circ} \mathrm{C}$, respectively. Generally, IRs in hamsters gradually decreased $(\mathrm{P}<0.05)$ by increasing the time passed after the ticks had the infective blood meal from 30 to 90 days (Table 2).

The present results agree with those of Piesman and Sinsky (1988) who found that efficiency of transmitting $B$. burgdorferi in $I$. scapularis had increased by increasing the number of feeding infected ticks per host animal. Also Lane et al. (1994) found that the plasma antibody titer to $B$. burgdorferi increased from 1 : 128 to $1: 256$ in mice exposed to feeding by one or two infected nymphs, respectively, of I. pacificus. Varma (1956) found that nymphs and young adults of $O$. turicata transmitted the infection with $B$. turicata better than old adults. He attributed this to a decrease in intensity or death of spirochetes in the salivary glands of old adults. Nikitina (1965) stated that $\mathrm{F}_{1}$ larvae of infected female $A$. persicus rarely transmitted $B$. anserina because there were few spirochetes in the larvae. She believed that after larvae had fed and digested the meal, spirochetes multiplied and their numbers in nymphs increased to a point of causing infection in fowl hosts. Crippa et al. (2002) demonstrated that transmission of $B$. burgdorferi from $I$. ricinus nymphs to mouse increased with duration of tick attachment. Balashov (1972) suggested that spirochetes within the tick body need to reach a threshold level to be able to infect vertebrate.

At each temperature tested in the present work, the gradual decrease of IRs in hamsters exposed to feeding of infected ticks after different time intervals following tick infective blood meal (30 to 90 days) suggested a decrease of efficiency in transmitting Borrelia sp. from $O$. savignyi to hamster as the post infection period of the tick was prolonged. This decrease might be attributed to the general decrease of IRs and no. of spirochetes or their disappearance (Helmy et al., 2009) from the tick organs (Helmy et al., 2009) during the delayed intervals of tick post infection $(60-90$ days); specially in organs responsible for transmitting infection to vertebrate host (salivary glands and coxal organ).

In the present study, EI temperature greatly influenced the efficiency of female $O$. savignyi in transmitting Borrelia $s p$. to hamster. Rearing the tick at $27^{\circ} \mathrm{C}$ was optimum for successful transmission of Borrelia $s p$. from the tick to hamster. At this temperature the highest IRs in hamsters occurred (Table 2). However, IRs in hamsters generally decreased $(\mathrm{P}<0.05)$ by lowering EI temperature to $17^{\circ} \mathrm{C}$ or rising it to $37^{\circ} \mathrm{C}$ in each of the corresponding experimental cases (number and post 
infection day of tick feeding per hamster) tested. Shih et al. (1995) suggested a maximal threshold temperature of EI to regulate susceptibility of the tick to infection and development of $B$. burgdorferi and to increase competence of the vector tick, $I$. dammini, as a host for Lyme disease spirochetes. They concluded that EI temperatures in excess of $27^{\circ} \mathrm{C}$ are not permissive for transmission of $B$. burgdorferi to mice and pointed at disappearance of spirochetes from all nymphs at $37^{\circ} \mathrm{C}$ as a possible reason of the tick failure in transmitting the spirochete to mice at this temperature. However, findings on effects of EI temperature on borrelial infection in organs of O. savignyi (Helmy et al., 2009) suggest that a decrease of IRs, no. and disappearance of spirochetes in organs of female $O$. savignyi might be considered as a possible reason of the decreased success of Borrelia transmission to hamsters at $17^{\circ} \mathrm{C}$ but not at $37^{\circ} \mathrm{C}$ as observed in the present study. Localization study of Borrelia $s p$. in various organs of female $O$. savignyi showed no significant difference between IRs and no. of spirochetes in each organ (including salivary glands and coxal organ) on the corresponding post infection days at $27^{\circ} \mathrm{C}$ and $37^{\circ} \mathrm{C}$ throughout a period of 90 days after the tick infective meal (Helmy et al., 2009). Therefore, the observed decrease of Borrelia $s p$. transmission to hamster at $37^{\circ} \mathrm{C}$ less than $27^{\circ} \mathrm{C}$ might be attributed to a probable change or interference with production of borrelial protein associated with transmission of spirochetes to the vertebrate host. Reciprocal expression of two main outer surface (lipo) proteins OspA and OspC occurs as $B$. burgdorferi is transmitted from its vector tick, $I$. scapularis, into mammalian host (Schwan et al., 1995). It was suggested that synthesis of OspC by spirochete during tick feeding may play an essential role in the capacity of $B$. burgdorferi to successfully infect mammalian host including human. A shift to higher temperatures $\left(34^{\circ} \mathrm{C}\right.$ and $37^{\circ} \mathrm{C}$ ) appears to be one important stimulus for triggering the induction of OspC (Schwan et al., 1995 and Yang et al,. 2000).

Contraversy between effects of temperature on transmission of spirochetes to vertebrate host might be attributed to differences between tick and borreliae species used in the aforementioned studies. For better understanding of the effects of temperature on transmission of Borrelia from ticks to vertebrate hosts further investigations are required on the outer surface and other proteins of borreliae not only in argasid ticks but also in ixodids other than I. scapularis.

\section{REFERENCES}

Balashov, Yu. S. (1972). Blood sucking ticks (Ixodidea). Vectors of disease of man and animals. Miscell. Pub. Entomol. Soc. Am., 8(5): 161-376.

Barbour, A.G. (1984). Isolation and cultivation of Lyme disease spirochetes. Yale J. Biol. Med., 57: 512-525.

Barbour, A.G.; Burgdorfer, W.; Hayes, S.F.; Peter, O. and Aeshliman, A. (1983). Isolation of cultivation spirochete from Ixodes ricinus ticks of Switzerland. Curr. Microbiol., 8: 123-126.

Cluss, R.G. and Boothby, J.T. (1990). Thermoregulation of protein synthesis in Borrelia burgdorferi. Infect. Immun., 58: 1038-1042.

Conn, H.J.; Darrow, M.A. and Emmel., V.M. (1960). Staining procedure used by the biological stain commission 2. ed. The Williams and Wilkins Company. Baltimore $289 \mathrm{pp}$.

Crippa, M.; Rais, O. and Gern, L. (2002). Investigation on the mode and dynamics of transmission and infectivity of Borrelia burgdorferi 
sensu stricto and Borrelia afzelii in Ixodes ricinus ticks. VectorBorne and Zoonotic diseases, 2(1): 3-9.

Cugini, C.; Medrano, M.; Schwan, T.G. and Coburn, J. (2003). Regulation of expression of the Borrelia burgdorferi B3 - chain integrin ligand, $P$ 66, in ticks and in culture. Infect. Immun. 71(2): 1001-1007.

Cunliffe, N. (1922). Some observation on the biology and structure of Ornithodoros savignyi Audoin. Parasitol., 14: 17-26.

Dalgliesh, R.J. and Stewart, N.P. (1982). Some effects of time, temperature and feeding on infection rates with Babesia bovis and Babesia bigemina in Boophilus microplus larvae. I.J.P. 12(4): 323-326.

Gaber, M.S.; Khalil, G.M.; Hoogstraal, H. and Abou-Nasr, A.E. (1984). Borrelia crocidurae localization and transmission in Ornithodoros erraticus and $O$. savignyi. Parasitol. 88: 403-413.

Hafez, M.; Abdel-Malek, A.A. and Guirgis, S.S. (1972). The subgenus persicargas (Ixodidae, Argasidae, Argas). 14. Biological studies on the adult stage of $A$. (P.) arboreus Kaiser, Hoogstraal and Kohls in Egypt. J. Med. Entomol. 9(1): 19-29.

Helmy, N. (2000a). Prevalence of Borrelia crocidurae in Ornithodoros (Pavlovskyella) erraticus (Acari: Argasidae) and rodent hosts in Egypt. J. Union Arab Biol. Cairo, 13(A): 193-212.

Helmy, N. (2000b). Seasonal abundance of Ornithodoros (O.) savignyi and prevalence of infection with Borrelia spirochetes in Egypt. J. Egy. Soc. Parasitol. 30(2): 607-619.

Helmy, N.; Abbas, A.A.; Abd El-Baky, S.M.; Abd El-Mohsen, A. and Awaad, E.S. (2006). Prevalence of Borrelial infection in tick vectors and vertebrate hosts in Giza governorate, Egypt. Sci. J. Fac. Sci. Min. Univ., vol. XX, 101-103.
Helmy, N.; Shanbaky, N.M.; Abd Elmohsen, A. and Abd El-hamid, A.E. (2009). Effect of extrinsic incubation temperature on borrelial infection in various organs of Ornithodoros (O.)savignyi. Egypt. Acad. J. biolog. Sci., 1(1):1-8.

Hoogstraal, H. (1985). Argasid and nuttalliellid ticks as parasites and vectors. Adv. Parasitol., 24: 135-238.

Injeyan, H.S.; Sweatman, G.K. and Matossian, R.M. (1971). Survival of Rickettsia conori in nymphal Rhipicephalus sangineus ticks at different temperatures. J. Med. Entomol., 8(4): 372-378.

Khalil, G.M. (1974). The subgenus Persicargas (Ixodidea; Argasidae: Argas). 19. Preliminary studies on diapauses in A. (P.) arboreus Kaiser, Hoogstraal and Kols. J. Med. Entomol., 11: 363-366.

Lane, R.S. and Manweiler, S.A. (1988). Borrelia coriaceae in its tick vector, Ornithodoros coriaceus (Acari: Argasidae), with emphasis on transstadial and transovarial infection. J. Med. Entomol., 25(3): 172-177.

Lane, R.S.; Brown, R.N.; Piesman, J. and Peavey, C.A. (1994). Vector competence of Ixodes pacificus and Dermacentor occidentalis (Acari: Ixodidae) for various isolates of Lyme disease spirochetes. J. Med. Entomol., 31(3): 417-424.

Lewengrub, S.; Rudzinska, M.A.; Piesman, J.; Spielman, A. and Zung, J.L. (1989). The influence of heat on the development of Babesia microti in unfed nymphs of Ixodes damminii. Can. J. Zool., 66: 1342-1345.

Naumov, R.L.; Va Silieva, I.S.; Gutova, V.P. and Erashova, A.S. (1998). Reproduction of the Lyme disease spirochete Borrelia burgdorferi S.I. in the taiga tick Ixodes persculactus. Parazitol., 32(5): 412-421.

Nikitina, R.E. (1965). On the transmission mechanism of the agent of bird spirochetosis by 
Argas persicus (Oken 1818) ticks. In Russian, English summary. Zool. Zh., 44(2): 294-296. In English: NAMRU3-T656.

Obonyo, M.; Munderloh, U.G.; Fingerle, V.; Wilske, B. and Kurtti, T.J. (1999). Borrelia burgdorferi in tick cell culture modulates expression of outer surface proteins $\mathrm{A}$ and $\mathrm{C}$ in response to temperature. J. Clin. Microbiol. 37(7): 2137-2141.

Ochanda, H.; Young, A.S.; Mutugi, J.J.; Mumo, J. and Omwoyo, P.L. (1988). The effect of temperature on the rate of transmission of Theileria parva parva infection to cattle by its tick vector, Rhipicephalus appendiculatus. Parasitol. 97: 239-245.

Ouhelli, H. Pandey, V.S. and Aboughal, A. (1987). Effect of infection by Babesia spp. on the development and survival of free-living stages of Boophilus annulatus. Vet. Parasitol., 23: 147-154.

Piesman, J. and Sinsky, R.J. (1988). Ability of Ixodes scapularis, Dermacentor variabilis, and Amblyomma americanum (Acari: Ixodidae) to acquire, maintain and transmit Lyme disease spirochetes (Borrelia burgdorferi). J. Med. Entomol., 25(5): 336-339.

Piesman, J.; Mather, T.N.; Donahue, J.G.; Levine, J.F.; Campbell, J.D.; Karakashion, S.J. and Spielman, A. (1986). Comparative prevalence of Babesia microti and Borrelia burgdorferi in four populations of Ixodes dammini in eastern Massachusetts. Acta Trop., 43: 263-270.

Ramamoorthy, R.; and Scholl, MD. (2001). Borrelia burgdorferi protein whose expression is similarly affected by culture temperature and $\mathrm{PH}$. Infect. Immun., 69(4): 2739-2742.
Schwan, T.G.; Piesman, J.; Golde, W.T.; Donlan, M.C. and Rosa, P.A. (1995). Induction of an outer surface protein on Borrelia burgdorferi during tick feeding. Proc. Natl. Acad. Sci. USA., 92: 2909-2913.

Shanbaky, N.M. and Helmy, N. (2000). First record of natural infection with Borrelia in Ornithodoros (Ornithodoros) savignyi reservoir potential and specificity of the tick to Borrelia. J. Egy. Soc. Parasitol. 30(3): 765-780.

Shih, M.C.; Telford, S.R. and Spielman, A. (1995).Effect of ambient temperature on competence of deer ticks as hosts for Lyme disease spirochetes. J. Clin. Microbiol., 33(4): 958-961.

Tatchell, R.J. (1964). Digestion in the tick, Argas persicus Oken. Parasitol., 54: 423-440.

Varma, M.G.R. (1956). Infections of Ornithodoros ticks, with relapsing fever spirochaetes, and the mechanisms of their transmission. Ann. Trop. Med. Parasitol., 50: 1831.

Yang, X.; Goldberg, M.S.; Popova, T.G.; Schoeler, G.B.; Wikel, S.K.; Hagmon, K.E. and Norgard, M.V. (2000). Interdependence of environmental factors influencing reciprocal patterns of gene expression in virulent Borrelia burgdorferi. Mol. Microbiol. 37(6): 1470-1479.

Young, A.S. and Leitch, B.L. (1981). Epidemiology of east coast fever: some effects of temperature on the development of Theileria parva in the tick vector, Rhipicephalus appendiculatus. Parasitol., 83: 199-211. 


\section{ARABIC SUMMARY}

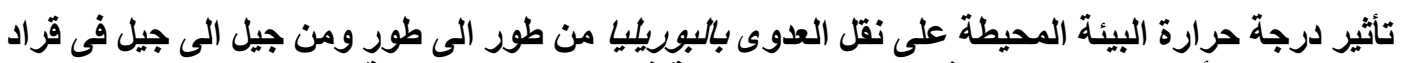

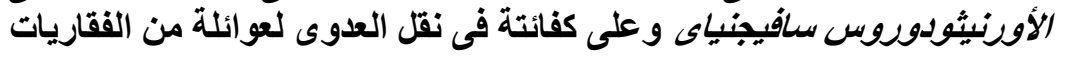

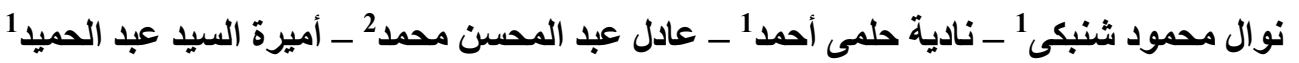

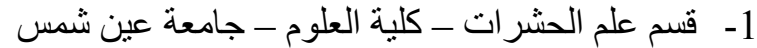

$$
\begin{aligned}
& \text { 2- مركز الأبحاث و الدر اسات و التنريب لناقلات الأمر اض ـ كلية العلوم - جامعة عين شمس }
\end{aligned}
$$

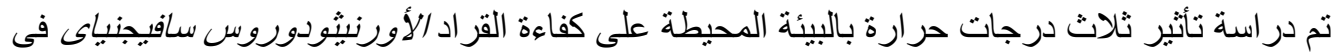

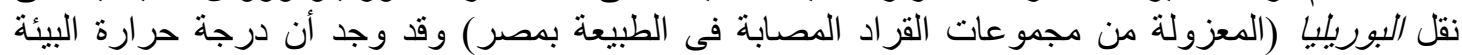

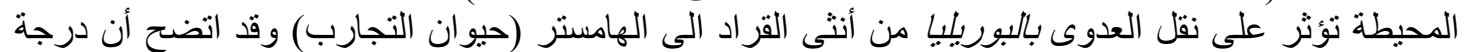

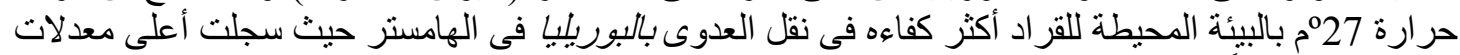

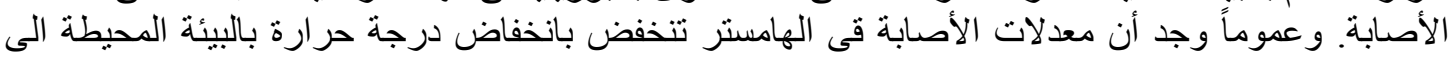

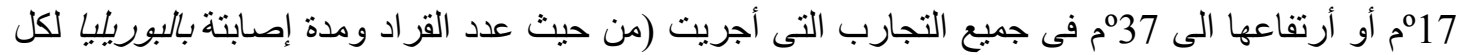

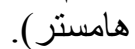

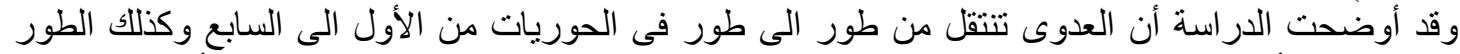

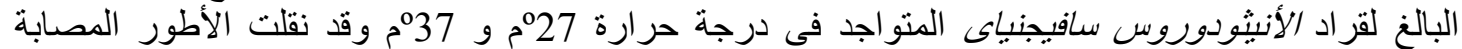

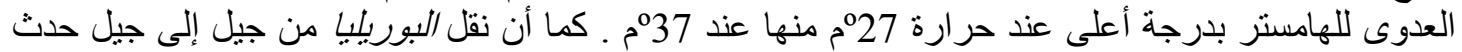

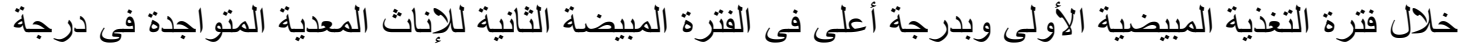

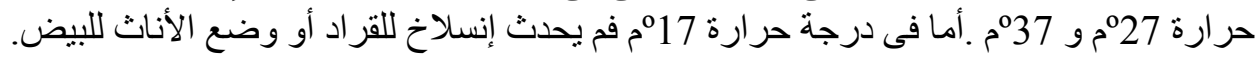

